\title{
Closure temperatures of the Sm-Nd system in metamorphic garnets
}

\author{
K. Mezger, E.J. Essene and A.N. Halliday \\ Department of Geological Sciences, C.C. Little Building, University of Michigan, Ann Arbor, MI 48109-1063, USA
}

Received December 17, 1991; revision accepted August 5, 1992

\begin{abstract}
Garnet-whole rock and garnet-mineral isochrons were determined on granulite facies gneisses and amphibolites from the Archean Pikwitonei Granulite Domain of the Superior Province, and the Proterozoic Central Gneiss Belt and Adirondack Highlands of the Grenville orogen. The Sm-Nd ages obtained from Archean garnets $0.1-0.5 \mathrm{~cm}$ in length are 30-110 Ma younger than the $\mathrm{U}-\mathrm{Pb}$ ages obtained on the same garnets and also younger than the time of the last regional metamorphism, as determined by the growth ages of the youngest metamorphic garnets and zircons. Similarly, the Sm-Nd ages obtained from Proterozoic garnets with a diameter of $0.1-5 \mathrm{~cm}$ are younger than the time of the last regional metamorphism and similar or younger than cooling ages obtained on sphenes from the same sample or from the same geologic setting. Only the core of a garnet with a diameter of ca. $30 \mathrm{~cm}$ and without abundant inclusions may record the time of garnet growth. Comparison of the Sm-Nd ages with other geochronologic data and temperature estimates leads to the conclusion that the closure temperature for the $\mathrm{Sm}-\mathrm{Nd}$ system in garnets analyzed in this study is ca. $600 \pm 30^{\circ} \mathrm{C}$. Only garnets with radii much larger than $5 \mathrm{~cm}$ may record $\mathrm{Sm}-\mathrm{Nd}$ growth ages in upper amphibolite facies rocks from slowly cooled terranes. Garnets from higher grade terranes yield cooling ages that define the retrograde history of metamorphic terranes.
\end{abstract}

\section{Introduction}

Garnet is the single most important mineral for obtaining information on pressures and temperatures in medium to high grade metamorphic rocks [e.g., 1,2]. Garnet is also an important mineral in many isogradic reactions and is one of the most widely used minerals for determining metamorphic $P-T$ paths [e.g., 3-9]. In addition, garnet can be used to obtain geochronological information with the Sm-Nd [e.g., 10-15], U-Pb $[16,17]$ and $\mathrm{Rb}-\mathrm{Sr}[18]$ decay schemes. Thus, garnet is the only major rock-forming mineral in metamorphic rocks that can yield high precision ages and, at the same time, provide information on $P-T$ conditions during its formation. In this respect dating of garnet has the potential to pro-

Correspondence to: K. Mezger, Max-Planck Institut für Chemie, Saarstraße 23, D-6500 Mainz, Germany. vide a better understanding of metamorphic processes than dating of accessory minerals. This information is critical for the construction of quantitative $P-T-t$ paths and to obtain information on rates of metamorphic processes. $P-T-t$ paths are essential for constraining important tectonothermal processes involved in the evolution of metamorphic terranes and thus large parts of the continental crust.

In order to utilize garnet chronometers meaningfully it is necessary to obtain ages which are highly precise and to evaluate whether an age represents the time of mineral growth or some time along the cooling path. As a result of advances in geochronological techniques, including sample preparation and mass spectrometry, it is now possible to obtain high precision $\mathrm{Sm}-\mathrm{Nd}$ ages that have an uncertainty of less than $1 \%$ for most Proterozoic and Archean samples. Such precision is essential for defining events within a single metamorphic episode. Currently the major problem in the interpretation of mineral ages is 
the evaluation of whether these dates represent growth ages or record the time at which the system cooled below a certain closure temperature $\left(T_{\mathrm{c}}\right)$ [19]. Therefore, it is necessary to have relevant information on the diffusion behavior of the parent-daughter system. Only if $T_{\mathrm{c}}$ is known would it be possible to use the mineral ages, combined with pressure and temperature estimates, to determine variations in the pressure and temperature conditions of metamorphism as a function of time, thus refining the understanding of $P-T-t$ paths.

\section{Sm-Nd systematics of garnets}

As a consequence of their identical charge and similar ionic radii, $\mathrm{Sm}$ and $\mathrm{Nd}$ are not fractionated sufficiently in any rock-forming mineral to obtain an age from a single mineral without significant correction for inherited $\mathrm{Nd}$. The Sm-Nd system can thus be used only if an isochron is constructed from at least two minerals or one mineral and the corresponding whole rock. The precision obtainable for a two-point isochron is, to a large extent, a function of the spread in the $\mathrm{Sm} / \mathrm{Nd}$ ratio of the two points. Garnet is one of the few rock-forming minerals that strongly prefers the heavy over the light rare earth elements, and it is the only common major rock-forming mineral in metamorphic rocks that discriminates sufficiently between $\mathrm{Sm}$ and $\mathrm{Nd}$ so that ages with a precision better than $1 \%$ can be obtained (at least on Precambrian samples). Such precision is comparable to that obtainable with the $\mathrm{K}-\mathrm{Ar}$ and $\mathrm{U}-\mathrm{Pb}$ systems. The use of $\mathrm{U}-\mathrm{Pb}$ geochronology on garnets is, in general, only successful in evolved igneous, meta-igneous or metasedimentary rocks [16]. Most intermediate to mafic rocks have $U$ concentrations that are too low to yield reliable age information. In addition, datable U-rich minerals, such as zircon or monazite, are extremely rare or absent in mafic and ultramafic rocks. Therefore, Sm-Nd geochronology is often the system chosen for garnet-bearing rocks to obtain a dating when it is difficult to obtain geochronologic information by other methods. Therefore, the Sm-Nd decay scheme has frequently been used to obtain mineral isochrons from garnet-bearing mafic and ultramafic rocks [e.g., 11,12,15].

\section{Closure temperatures}

Closure temperatures must be known in order to relate the ages obtained from minerals to geologic processes and events. The $T_{\mathrm{c}}$ cannot be calculated from first principles and therefore has to be determined empirically. This can be done through experiments [20-22] or in geologic settings where the thermal history can be evaluated using a variety of minerals with different known $T_{\text {c }}$ 's [e.g., $\left.17,23,24\right]$.

The $T_{\mathrm{c}}$ of the parent-daughter system, and ideally its dependence on composition, cooling rate, grain size and geometry, for each phase is requisite knowledge for the interpretation of mineral isochrons. In addition, it is important to evaluate with which other phase(s) the mineral under consideration was in isotopic equilibrium at the time recorded by the isochron. Some of the ambiguities of multi-mineral isochrons can be removed by constructing a two point whole-rockmineral isochron. The interpretation of such an isochron is based on the assumption that the whole rock represents a closed system and is equivalent to the last assemblage with which the mineral equilibrated.

It is possible to assess the $T_{\mathrm{c}}$ for the $\mathrm{Sm}-\mathrm{Nd}$ system in garnets by comparing the garnet $\mathrm{Sm}-\mathrm{Nd}$ age with ages obtained from other minerals with known $T_{\mathrm{c}}$ in the same rock or same geologic unit and the maximum temperature achieved in these rocks, as determined by careful thermometry. Therefore, samples for this study were chosen so that comparisons with the regional metamorphic grade and other thermochronometric information already available ( $\mathrm{U}-\mathrm{Pb}$ data on zircon, sphene, monazite, rutile and allanite; $\mathrm{K}-\mathrm{Ar}$ and ${ }^{40} \mathrm{Ar} /{ }^{39} \mathrm{Ar}$ data on hornblende, phlogopite, muscovite, biotite and Kfeldspar) would allow estimates of $T_{\mathrm{c}}$ and/or growth temperatures of the Sm-Nd systems in garnets of different compositions.

Humphries and Cliff [25] concluded that the $T_{c}$ for the $\mathrm{Sm}-\mathrm{Nd}$ system in garnets is in the range $500-700^{\circ} \mathrm{C}$; based on the extrapolation of hightemperature experimental diffusion data by Harrison and Wood [26]. However, due to the design and the high temperatures of the experiments, the diffusion data derived is questionable [27]. In a recent study on coronitic anorthosite granulites from Norway, Cohen et al. [14] suggested that 
garnets preserve their Sm-Nd systematics up to $900^{\circ} \mathrm{C}$. This high temperature is consistent with the proposed $T_{c}$ of $>850^{\circ} \mathrm{C}$ for the system garnet-clinopyroxene from an eclogite xenolith studied in detail by Jagoutz [14]. However, in both cases no other geochronologic information from systems with known diffusion behavior was available that would allow an assessment of whether the Sm-Nd system records the time of garnet growth or some later date when the garnets closed to diffusion.

\section{Sampling}

The garnets selected for this study are from the Archean Pikwitonei Granulite Domain in Manitoba, Canada [16,28] and the Proterozoic Grenville orogen in Ontario, Canada and New
York, USA, [e.g. 29,30]. The metamorphic history $(P-T-t$ path) for the Pikwitonei Granulite Domain was studied using geothermobarometry [28] and geochronology on zircon, garnet, rutile and sphene $[16,17,31]$. Mineral ages on zircon, garnet, sphene, monazite, rutile, hornblende and biotite are available for the Adirondacks [e.g., 32-34]. For the Central Gneiss Belt mineral ages were determined on zircon, baddeleyite, monazite, sphene, hornblende and biotite [e.g., 30,35-38]. The conditions for peak metamorphism of the Grenville orogen are summarized by Bohlen et al. [7] for the Adirondacks and by Anovitz and Essene [39] for the Grenville orogen in Ontario. The available geochronological data provide a detailed picture of the $T-t$ paths above $400^{\circ} \mathrm{C}$ for all three areas from which samples were chosen for this study. Thus, the critical information

TABLE 1

Compilation of radiometric ages (in $\mathrm{Ma}$ )

\begin{tabular}{|c|c|c|c|c|c|c|}
\hline Sample & Sm-Nd age & Other ages & Mineral & System & Age & References \\
\hline \multicolumn{7}{|c|}{$\begin{array}{l}\text { Pikwitonei Granulite Domain } \\
\text { Cauchon Lake }\end{array}$} \\
\hline \multirow[t]{2}{*}{217} & $2576 \pm 5$ & same sample & garnet & $\mathbf{U}-\mathbf{P b}$ & $2687 \pm 1$ & 16 \\
\hline & & & rutile & $\mathrm{U}-\mathbf{P b}$ & $2430 \pm 2$ & 17 \\
\hline \multirow[t]{4}{*}{64} & $2605 \pm 9$ & same sample & garnet & $\mathrm{U}-\mathrm{Pb}$ & $2637 \pm 5$ & 16 \\
\hline & & same area & zircon & $\mathrm{U}-\mathrm{Pb}$ & $2695-2598$ & 31 \\
\hline & & & garnet & $\mathrm{U}-\mathrm{Pb}$ & $2984-2591$ & 16 \\
\hline & & & rutile & $\mathrm{U}-\mathrm{Pb}$ & 2430 & 17 \\
\hline \multicolumn{7}{|c|}{ Grenville Orogen } \\
\hline \multicolumn{7}{|c|}{ Central Gneiss Belt } \\
\hline \multirow[t]{9}{*}{ CHF2 } & $1019 \pm 3$ & same sample & sphene & $\mathrm{U}-\mathrm{Pb}$ & $1039 \pm 2$ & 38 \\
\hline & & & hornblende & ${ }^{40} \mathrm{Ar} /{ }^{39} \mathrm{Ar}$ & $1006 \pm 4$ & 30 \\
\hline & & same area & zircon & $\mathrm{U}-\mathrm{Pb}$ & 1170,1060 & 36,37 \\
\hline & & & baddeleyite & $\mathrm{U}-\mathrm{Pb}$ & 1170,1060 & 36,37 \\
\hline & & & monazite & $\mathrm{U}-\mathrm{Pb}$ & 1100,1074 & 38 \\
\hline & & & sphene & $\mathrm{U}-\mathrm{Pb}$ & 1075 & 38 \\
\hline & & & hornblende & ${ }^{40} \mathrm{Ar} /{ }^{39} \mathrm{Ar}$ & $1005-930$ & 30 \\
\hline & & & biotite & ${ }^{40} \mathrm{Ar} /{ }^{39} \mathrm{Ar}$ & $918-869$ & 30 \\
\hline & & & muscovite & ${ }^{40} \mathrm{Ar} /{ }^{39} \mathrm{Ar}$ & 870 & 30 \\
\hline \multicolumn{7}{|c|}{ Adirondacks (Gore Mountain) } \\
\hline CCL & $1051 \pm 4$ & & & & & \\
\hline GM (rim) & $1029 \pm 3$ & & & & & \\
\hline \multirow[t]{8}{*}{ GM (core) } & $1018 \pm 7$ & & & & & \\
\hline & & same area & zircon & $\mathrm{U}-\mathrm{Pb}$ & 1156,1150 & 33 \\
\hline & & & garnet & $\mathrm{U}-\mathrm{Pb}$ & 1154,1064 & 34 \\
\hline & & & monazite & $\mathrm{U}-\mathrm{Pb}$ & 1033 & 34 \\
\hline & & & sphene & $\mathrm{U}-\mathrm{Pb}$ & $1033-991$ & 34 \\
\hline & & & rutile & $\mathrm{U}-\mathrm{Pb}$ & 911,885 & 17 \\
\hline & & & hornblende & ${ }^{40} \mathrm{Ar} /{ }^{39} \mathrm{Ar}$ & $950-900$ & 32 \\
\hline & & & biotite & ${ }^{40} \mathrm{Ar} /{ }^{39} \mathrm{Ar}$ & $853-810$ & 32 \\
\hline
\end{tabular}


needed for evaluation of the $T_{\mathrm{c}}$ for the $\mathrm{Sm}-\mathrm{Nd}$ system in garnets is available.

\subsection{Pikwitonei Granulite Domain}

\subsubsection{Cauchon Lake area}

The zircons and garnets in this Archean high grade terrane yielded $\mathrm{U}-\mathrm{Pb}$ ages that indicate that this terrane had undergone three different metamorphic episodes at about $2740 \mathrm{Ma}, 2700$ $2687 \mathrm{Ma}$ and 2660-2640 Ma [16,31]. The last metamorphism reached peak temperatures of $750^{\circ} \mathrm{C}$ and pressures of ca. 7 kbar. Pegmatites and minimum melt granites intruded at ca. $2600-2590$ $\mathrm{Ma}$, indicating that the area had reached $<650^{\circ} \mathrm{C}$ at this time [28]. Subsequently, the terrane cooled further and reached ca. $430^{\circ} \mathrm{C}$, the $T_{\mathrm{c}}$ for the $\mathrm{U}-\mathrm{Pb}$ system in rutile $[17,28]$ at $2430 \mathrm{Ma}$ (Table 1). In this study the following samples from the Pikwitonei Granulite Domain were used:

217: Garnet-biotite-plagioclase-K-feldsparquartz-sillimanite-cordierite-ilmenite-spinelrutile-graphite-monazite-zircon. The garnets in this sample $0.1-0.5 \mathrm{~cm}$ in length were dated by the $\mathrm{U}-\mathrm{Pb}$ technique and yielded an age of 2687 \pm 1 Ma [16]. The rock was overprinted by a subsequent metamorphic episode that reached ca. $750^{\circ} \mathrm{C}$ at $2640 \mathrm{Ma}$. Rutile from this sample yielded a U-Pb age of $2430 \mathrm{Ma}$ [17].

64: K-feldspar-quartz-garnet. The garnets $0.1-0.3 \mathrm{~cm}$ in length yielded a K-feldspar-garnet $\mathrm{Pb}-\mathrm{Pb}$ age of $2637 \pm 5 \mathrm{Ma}$ [16]. This age is consistent with other garnet and $\mathrm{U}-\mathrm{Pb}$ zircon ages from this area [16,31] and dates garnet growth during the last regional metamorphic episode.

\subsection{Grenville orogen}

\subsubsection{Central Gneiss Belt}

From the Grenville orogen the following amphibolite samples were selected:

CHF2: Hornblende-plagioclase-K-feldsparbiotite-garnet-sphene. The garnets in this amphibolite had a diameter of 0.1 to $0.2 \mathrm{~cm}$. A $\mathrm{U}-\mathrm{Pb}$ sphene age of $1039 \pm 2 \mathrm{Ma}$ was obtained for this sample. Other sphenes and monazites from this part of the Grenville orogen yielded ages from 1100 to $1074 \mathrm{Ma}$ [38]. The ${ }^{40} \mathrm{Ar} /{ }^{39} \mathrm{Ar}$ system yielded an age of $1006 \pm 4 \mathrm{Ma}$ for hornblende from the same sample and ages ranging from 1005 to $930 \mathrm{Ma}$ for other hornblendes from the same area [30].

\subsubsection{Adirondack Highlands}

The following samples were selected from the Adirondack Highlands:

GM, CCL: Garnet-hornblende-plagioclasehypersthene-biotite-ilmenite-rutile-apatitepyrrhotite-pyrite-zircon. The samples were chosen because they contained large garnets (up to $50 \mathrm{~cm}$ ). Most garnets from this locality (Gore Mountain) have only minor amounts of inclusions. From one of these garnets an isochron was obtained using material from the core of the garnet and amphibole from the matrix (sample $\mathrm{CCL}$ with a diameter of $30 \mathrm{~cm}$ ). Some rare samples have a core consisting of garnet-hypersthene-plagioclase-biotite-ilmenite and a rim that has only trace amounts of biotite and rutile inclusions. Such a garnet, with a diameter of 14 $\mathrm{cm}$, was chosen in order to obtain separate Sm$\mathrm{Nd}$ isochrons for the core and the rim assemblage. For the rim isochron hornblende and plagioclase from the matrix immediately adjacent to the garnet rim were taken. Due to the large grain size of the minerals, particularly the garnet, it was not feasible to obtain a representative whole-rock sample for isotope analysis.

No direct age information was available for the Gore Mountain garnet, but $\mathrm{U}-\mathrm{Pb}$ zircon, garnet, sphene and rutile ages have been determined previously in this area and indicate that this section of the Adirondack Highlands underwent metamorphism at ca. $1150 \mathrm{Ma}$ and at 1100-1050 Ma [33,34]. The last regional metamorphism reached temperatures of ca. $700^{\circ} \mathrm{C}$ [29] in the area of Gore Mountain. Subsequently, the terrane cooled and reached ca. $430^{\circ} \mathrm{C}$ at $900 \mathrm{Ma}$, as indicated by $\mathrm{U}-\mathrm{Pb}$ ages obtained on rutile [17] (Table 1).

\section{Composition of the garnets}

The end-member compositions of the garnets are given in Table 2. The garnets from the metapelite (sample 217) and meta-rhyolite (sample 64) are predominantly almandine-pyrope solid solutions with minor spessartine and grossular components. Both samples are homogeneous with respect to their major element composition and 
show only a thin rim (ca. $30 \mathrm{~mm}$ ) with an elevated $\mathrm{Fe} / \mathrm{Mg}$ ratio [28] The garnets from the amphibolites are almandine-pyrope-grossular solid solutions with minor spessartine component. All these garnets show significant major element zoning within individual grains and in the garnets from Gore Mountain, even within individual segments used for the isotope study. The garnets from Gore Mountain exhibit pronounced prograde zoning, with a marked increase in pyrope and grossular components from core to rim and a corresponding decrease in the almandine and spessartine components (Table 2).

\section{Analytical techniques}

The minerals were separated from crushed rocks using heavy liquids and a Frantz Isodynamic separator. High purity separates were subsequently handpicked under a binocular microscope. From the garnet sample GM a slab about $1 \mathrm{~cm}$ thick was cut through the center of the crystal. A piece about $2 \mathrm{~cm}$ wide was cut through the center of this slab. This piece was cut again into seven segments about $1 \mathrm{~cm}$ wide from core to rim. One piece from the core and the rim were crushed and the different phases were picked under the binocular microscope. The minerals were washed in warm, ca. $2 M \mathrm{HCl}$ for several hours to remove surface contamination. Prior to dissolution the garnets were crushed to $<0.5$ $\mathrm{mm}$. The whole rock powders were obtained by repeated crushing and splitting from 1 to $5 \mathrm{~kg}$ samples. The garnets were digested in a mixture of concentrated $\mathrm{HF}, \mathrm{HNO}_{3}$ and $\mathrm{H}_{2} \mathrm{SO}_{4}$. The hornblende and plagioclase separates, as well as the whole rock powders were dissolved in a mixture of concentrated $\mathrm{HF}$ and $\mathrm{HNO}_{3}$. All samples were digested in $3 \mathrm{ml}$ screw-top Teflon PFA® vials inside Krogh-style Teflon ${ }^{\circledR}$ bombs or Parr ${ }^{\circledR}$ bombs at $210^{\circ} \mathrm{C}$ for up to 1 week. Subsequent to drying down, the samples were redissolved in $6 \mathrm{M}$ $\mathrm{HCl}$. The addition of $\mathrm{H}_{2} \mathrm{SO}_{4}$ to the garnets at the digestion step has the advantage that dissolution of the fluorides in $\mathrm{HCl}$ can be achieved more readily than in cases where no $\mathrm{H}_{2} \mathrm{SO}_{4}$ is used. However, if there was still any trace of residue, the clear solution was removed and saved. The residue was treated again in the same manner as the original sample. After complete dissolution was achieved, the solutions were combined and then aliquoted for spiking. One part of the solution was spiked with a mixed ${ }^{149} \mathrm{Sm}-{ }^{150} \mathrm{Nd}$ tracer and rehomogenized on a hot plate for 1 day. Subsequently, the samples were dried and then redissolved for cation exchange column chemistry. The REE were separated as a group using BioRad AG50W-X8 (200-400 mesh) and Sm and Nd were separated using HDHP-PTFE columns. For analysis $\mathrm{Sm}$ and $\mathrm{Nd}$ were loaded separately on Ta-Re triple filaments and run as metal. Analyses were performed in the Radiogenic Isotope Geochemistry Laboratory at the University of Michigan using two VG Sector mass spectrometers. All $\mathrm{Nd}$ isotope ratios were normalized to ${ }^{146} \mathrm{Nd} /{ }^{144} \mathrm{Nd}=0.7219$. During the course of this study the value obtained for La Jolla Nd-standard was $0.511858 \pm 10(2 \sigma)$. For all isochron calculations in this paper a minimum uncertainty of $\pm 0.0020 \%(2 \sigma \mathrm{m})$ was assumed for the measured ${ }^{143} \mathrm{Nd} /{ }^{144} \mathrm{Nd}$ ratios, based on the reproducibility of the standard. If the standard error of an analysis was higher than $\pm 0.0020 \%(2 \sigma \mathrm{m})$, the higher value was used. The uncertainty for the $\mathrm{Sm} / \mathrm{Nd}$ ratio was taken as $0.15 \%$. The total procedural blank for Nd was $<20 \mathrm{pg}$. Since ca. 100-200 ng

TABLE 2

End-member composition of garnets

\begin{tabular}{|c|c|c|c|c|c|c|}
\hline \multirow[t]{3}{*}{ Mineral } & \multicolumn{6}{|c|}{ Sample } \\
\hline & \multicolumn{2}{|c|}{ Pikwitonei } & \multicolumn{3}{|c|}{ Gore Mountain } & \multirow{2}{*}{$\frac{\mathrm{CGB}}{\mathrm{CHF} 2}$} \\
\hline & 64 & 217 & GM1 & GM7 & $\mathrm{CCL}$ & \\
\hline Almandine (\%) & 70 & 62 & $54-58$ & $41-45$ & $48-49$ & $57-64$ \\
\hline Pyrope (\%) & 22 & 34 & $31-34$ & $38-43$ & $38-40$ & $12-13$ \\
\hline Grossular (\%) & 4 & 2 & $9-11$ & $12-17$ & 11 & $21-29$ \\
\hline Spessartine (\%) & 4 & 3 & $2-2$ & 1 & 1 & $2-3$ \\
\hline
\end{tabular}


of $\mathrm{Nd}$ were used for an individual isotope analysis the procedural blank was negligible.

\section{Results}

The Sm and Nd concentrations and the isotopic composition of $\mathrm{Nd}$ from the minerals and whole-rock samples measured for this study are given in Table 3. The reproducibility of the ${ }^{147} \mathrm{Sm} /{ }^{144} \mathrm{Nd}$ and ${ }^{143} \mathrm{Nd} /{ }^{144} \mathrm{Nd}$ ratios of the garnets are well outside analytical uncertainty but reproduce well for the plagioclase. Despite this poor reproducibility of the ratios in garnet, the data points lie on the respective isochrons. This indicates that there is substantial zoning in the $\mathrm{Sm}$ and $\mathrm{Nd}$ concentrations in the garnets and it is essential to obtain concentrations and isotopic ratios from the same homogeneous aliquot. For this reason all samples used in this study were split after a completely clear solution of the material was obtained.

The two garnet-whole rock isochrons for the samples from the Pikwitonei Granulite Domain yielded ages of $2605 \pm 9 \mathrm{Ma}$ (Fig. 1a) and $2576 \pm 5$ $\mathrm{Ma}$ (Fig. 1b). These ages are significantly younger than the time of last metamorphism, which lasted from about 2660-2640 Ma [16,31]. Based on twofeldspar thermometry, combined with $\mathrm{U}-\mathrm{Pb}$ ages from zircons and garnets, peak temperatures of about $750^{\circ} \mathrm{C}$ were reached in the Cauchon Lake area during the last peak of regional metamorphism at ca. $2640 \mathrm{Ma}$. Since the Sm-Nd ages are significantly younger, this temperature is an upper limit for the $T_{\mathrm{c}}$ of the $\mathrm{Sm}-\mathrm{Nd}$ system in garnet. Comparison of the $\mathrm{Sm}-\mathrm{Nd}$ with the $\mathrm{U}-\mathrm{Pb}$ age for sample 217 also indicates that the $\mathrm{Sm}-\mathrm{Nd}$

TABLE 3

Analytical results

\begin{tabular}{|c|c|c|c|c|}
\hline Sample & $\begin{array}{l}\text { Sm } \\
\text { (ppm) }\end{array}$ & $\begin{array}{l}\text { Nd } \\
\text { (ppm) }\end{array}$ & ${ }^{147} \mathrm{Sm} /{ }^{144} \mathrm{Nd}$ & ${ }^{.143} \mathrm{Nd} /{ }^{144} \mathrm{Nd}^{\mathrm{a}}$ \\
\hline \multicolumn{5}{|c|}{ Pikwitonei Granulite Domain } \\
\hline \multicolumn{5}{|c|}{ Cauchon Lake } \\
\hline $217 \mathrm{wr}^{\mathrm{b}}$ & 2.521 & 15.27 & 0.09975 & $0.510819 \pm 5$ \\
\hline $217 \mathrm{ga}$ & 4.589 & 3.249 & 0.8562 & $0.523669 \pm 6$ \\
\hline $64 \mathrm{wr}$ & 1.323 & 8.421 & 0.09493 & $0.510559 \pm 5$ \\
\hline $64 \mathrm{ga} / 3$ & 6.647 & 1.921 & 2.108 & $0.545211 \pm 7$ \\
\hline $64 \mathrm{ga} / 2$ & 6.381 & 1.883 & 2.064 & $0.544327 \pm 18$ \\
\hline \multicolumn{5}{|c|}{ Grenville Orogen } \\
\hline \multicolumn{5}{|c|}{ Central Gneiss Belt } \\
\hline CHF2 wr & 10.98 & 78.69 & 0.1392 & $0.512156 \pm 5$ \\
\hline CHF2 ga $/ 1$ & 4.571 & 2.744 & 1.009 & $0.517989 \pm 4$ \\
\hline $\mathrm{CHF} 2 \mathrm{ga} / 2$ & 4.592 & 2.587 & 1.075 & $0.518374 \pm 15$ \\
\hline $\mathrm{CHF} 2 \mathrm{hbl} / 1$ & 45.32 & 161.9 & 0.1692 & $0.512380 \pm 6$ \\
\hline $\mathrm{CHF} 2 \mathrm{hbl} / 2$ & 46.45 & 168.2 & 0.1669 & $0.512350 \pm 5$ \\
\hline \multicolumn{5}{|c|}{ Adirondack Highlands } \\
\hline GM1 ga /1 & 1.066 & 0.5413 & 1.193 & $0.519451 \pm 7$ \\
\hline GM1 ga/2 & 1.050 & 0.4899 & 1.298 & $0.520103 \pm 6$ \\
\hline GM1 ga $/ 3$ & 1.034 & 0.4758 & 1.316 & $0.520268 \pm 6$ \\
\hline GM1 hyp & 4.299 & 15.65 & 0.1661 & $0.512571 \pm 12$ \\
\hline GM1 plag & 0.1620 & 1.507 & 0.06498 & $0.511991 \pm 20$ \\
\hline GM7 ga / 1 & 0.7166 & 0.4966 & 0.8735 & $0.517379 \pm 9$ \\
\hline GM7 ga/2 & 0.8599 & 0.5650 & 0.9213 & $0.517710 \pm 19$ \\
\hline GM7 plag & 0.06461 & 0.7945 & 0.04915 & $0.511829 \pm 14$ \\
\hline GM8 plag & 0.06126 & 0.7548 & 0.04906 & $0.511814 \pm 11$ \\
\hline GM8 hbl & 4.289 & 16.09 & 0.1611 & $0.512565 \pm 5$ \\
\hline CCL ga & 0.5440 & 0.4652 & 0.7076 & $0.516315 \pm 8$ \\
\hline CCL hbl & 2.936 & 11.81 & 0.1503 & $0.512472 \pm 5$ \\
\hline
\end{tabular}

a normalized to ${ }^{146} \mathrm{Nd} /{ }^{144} \mathrm{Nd}=0.7219$, errors are $2 \sigma_{\mathrm{m}}$.

${ }^{b} \mathrm{ga}=$ garnet; $\mathrm{hbl}=$ hornblende; hyp = hypersthene; plag = plagioclase; $w r=$ whole rock. 

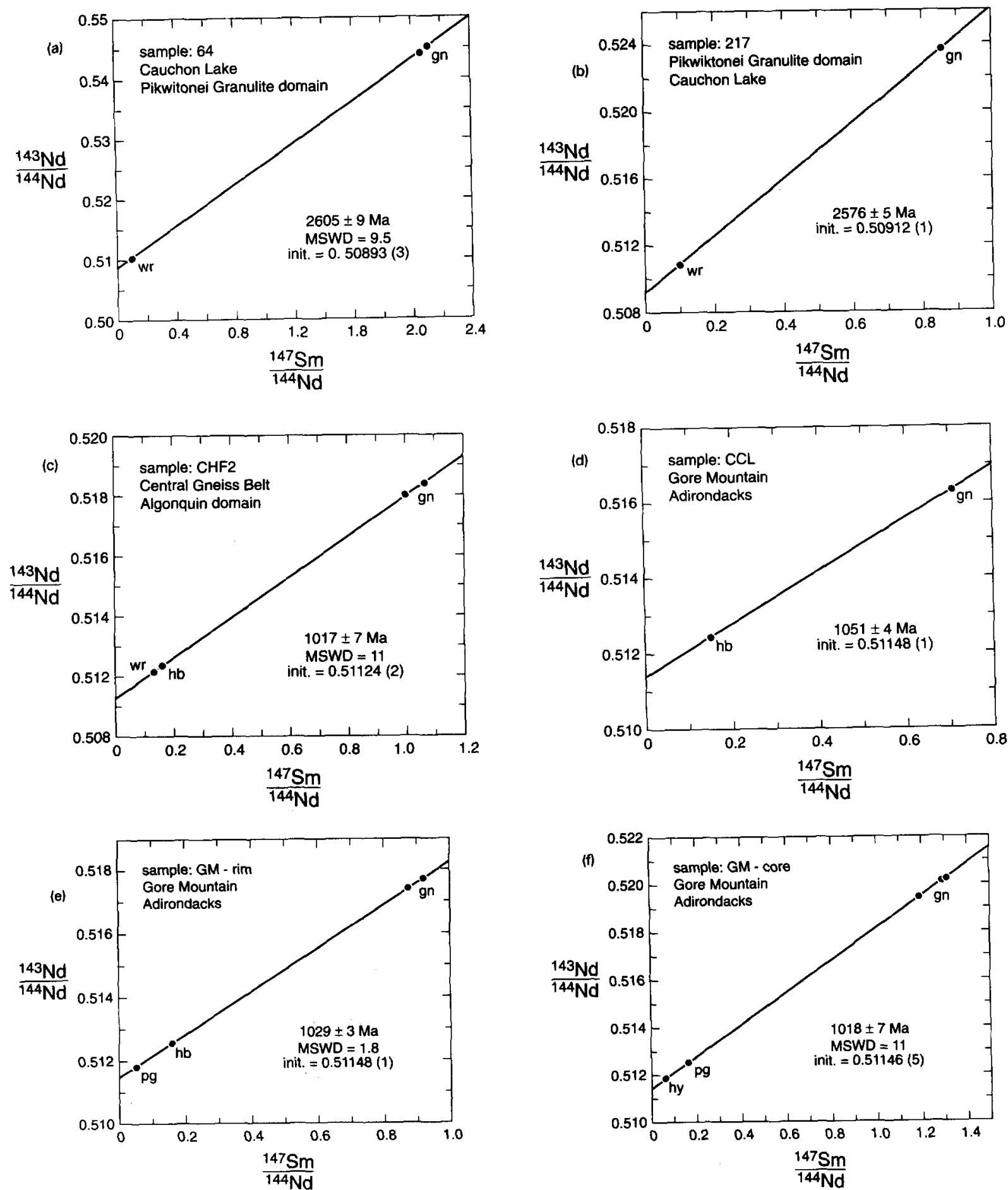

Fig. 1. (a) Sm-Nd isochron diagram with analyses of garnet $(g n)$ separates and whole rock (wr) sample 64 from the Pikwitonei Granulite Domain. (b) Sm-Nd isochron diagram with analysis of gamet separates and whole rock sample 217 from the Pikwitonei Granulite Domain. (c) Sm-Nd isochron diagram with analyses of gamet, homblende ( $h b l$ ) separates and whole rock sample CHF2 from Central Gneiss Belt of the Grenville orogen. (d) Sm-Nd isochron diagram with analyses of garnet and hornblende separates from sample CCL from Gore Mountain, Adirondack Highlands. (e) Sm-Nd isochron diagram with analyses of garnet, plagioclase ( $p g$ ) and homblende separates from the rim of sample GM from Gore Mountain, Adirondack Highlands. (f) Sm-Nd isochron diagram with analysis of garnet and hypersthene $(h y)$ separates from the core of sample GM from Gore Mountain, Adirondack Highlands. If the plagioclase analysis is included the minerals yield an age of $1011 \pm 11 \mathrm{Ma}(\mathrm{MSWD}=42.4)$. 
systematics in this garnet were completely reset during the last regional metamorphism whereas the $\mathrm{U}-\mathrm{Pb}$ systematics survived this high grade metamorphism (Table 1). Comparison of the SmNd ages obtained in this study with the $T-t$ path for these samples (Fig. 2a) [28] indicates that the $T_{\mathrm{c}}$ for the $\mathrm{Sm}-\mathrm{Nd}$ system in these almandine-py-
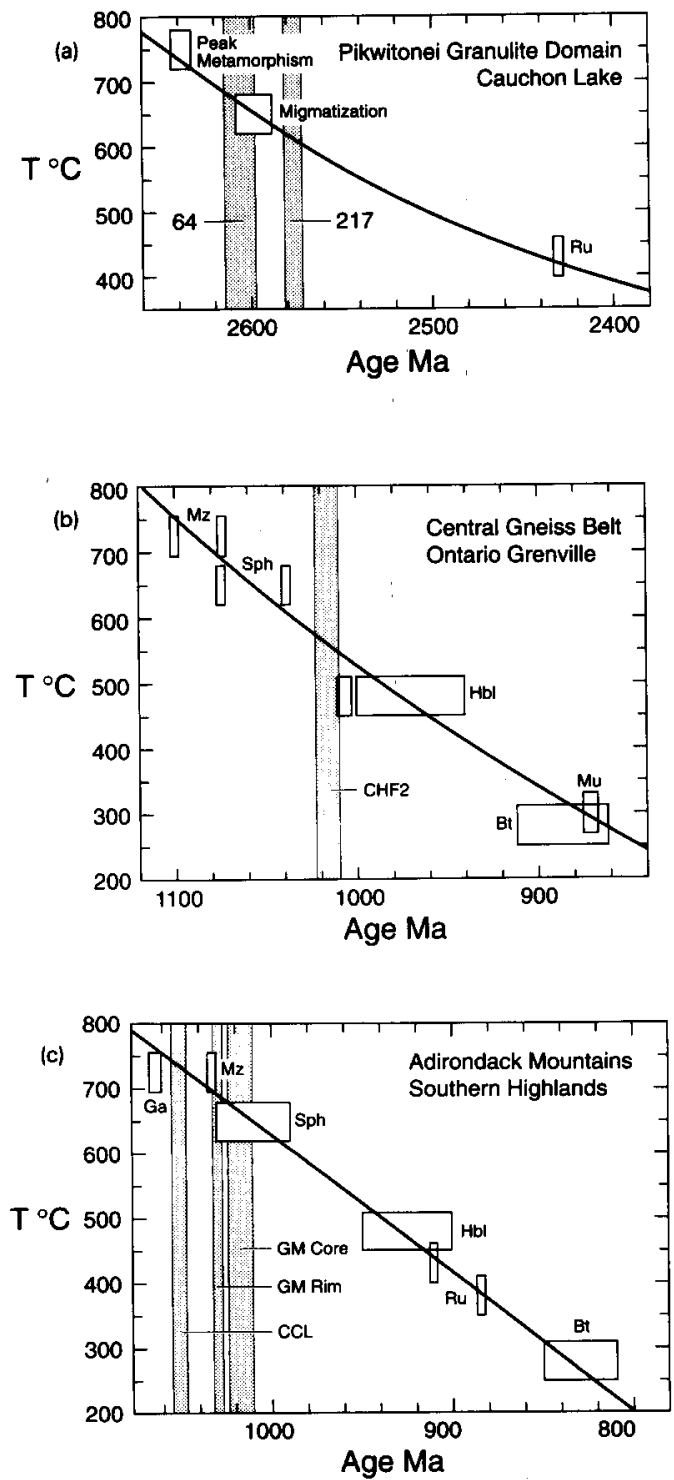

Fig. 2. Temperature-time paths for (a) the Pikwitonei Granulite Domain; (b) the Central Gneiss Belt of the Grenville orogen; and (c) the southern Adirondack Highlands. Shaded bars $=$ the $\mathrm{Sm}-\mathrm{Nd}$ ages for the different samples; $B t=$ biotite; $G a=$ garnet; $H b l=$ hornblende; $M u=$ muscovite; $M z=$ monazite; $R u=$ rutile; $S p h=$ sphene.

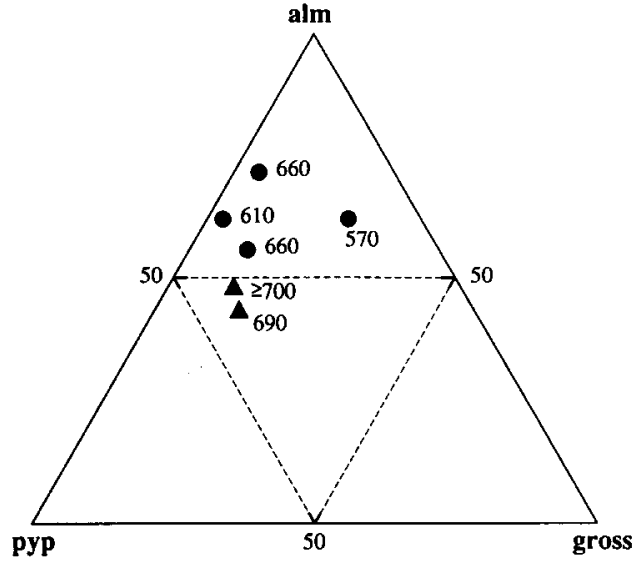

Fig. 3. This ternary diagram shows the average composition of the garnets used in this study (Table 2) combined with the closure temperatures derived from the cooling histories (Fig. 2). Dots = garnets with a diameter of $0.1-0.5 \mathrm{~cm}$; solid triangles $=$ the large garnets with a diameter of $5 \mathrm{~cm}$ (sample GM rim) and $30 \mathrm{~cm}$ (sample CCL). Since the estimated uncertainties for $T_{\mathrm{c}}$ are at least $30^{\circ} \mathrm{C}$, there is no significant correlation between the estimated $T_{\mathrm{c}}$ and garnet composition. The apparently higher $T_{c}$ obtained for the large garnets is most likely a size, not a composition, effect.

rope dominated garnets from a meta-rhyolite and a meta-pelite is about $600-650^{\circ} \mathrm{C}$.

Amphibolite sample CHF2 from the Central Gneiss Belt of the Grenville orogen yields a SmNd hornblende-garnet-whole rock age of $1017 \pm$ $7 \mathrm{Ma}$ (Fig. 1c). This area experienced peak metamorphic temperatures of about $780^{\circ} \mathrm{C}$ [39]. Sphene from the same rock yielded a concordant $\mathrm{U}-\mathrm{Pb}$ age of $1039 \pm 2 \mathrm{Ma}$. Assuming that this sphene closed for the U-Pb system at ca. 600-

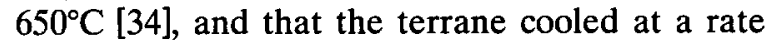
of $2-4^{\circ} \mathrm{C} / \mathrm{Ma}$ [30] this yields a $T_{\mathrm{c}}$ of $610-520^{\circ} \mathrm{C}$ for the $\mathrm{Sm}-\mathrm{Nd}$ system in this garnet (Fig. 2b). This range of $T_{\mathrm{c}}$ values is consistent with the ${ }^{40} \mathrm{Ar} /{ }^{39} \mathrm{Ar}$ hornblende age of $1006 \mathrm{Ma}\left(T_{\mathrm{c}}=\right.$ $480^{\circ} \mathrm{C}$ ) obtained on the same sample by Cosca et al. [30]. Although the major element composition of this garnet is very different from the garnets from the Pikwitonei domain there does not seem to be a significant difference in the $T_{\mathrm{c}}$ for Ca-poor garnets from the Pikwitonei domain and the $\mathrm{Ca}$ rich garnets from the Central Gneiss Belt (Fig. 3).

The peak temperature for the last regional metamorphism experienced by the garnets from Gore Mountain was about $700^{\circ} \mathrm{C}$ [29] and was reached at 1100-1050 $\mathrm{Ma}$ [34]. The core of the 
garnet sample CCL (30 cm long) with a hornblende from the matrix yields an age of $1051 \pm 4$ Ma (Fig. 1d), which corresponds to the late stages of the regional metamorphism. This age is similar to the $\mathrm{Sm}-\mathrm{Nd}$ isochron age of $1059 \pm 19 \mathrm{Ma}$ obtained on plagioclase, hornblende and garnet from the same outcrop by Basu et al. [40]. However, these authors do not give any information on the size of the garnets nor the location of the material within these garnets used to obtain the isochron. Therefore, a direct comparison with the results presented here is not possible. Since no other age information on the samples from Gore Mountain is available, the age of $1151 \mathrm{Ma}$ can either be interpreted as a growth age or it may date very early cooling. In contrast, the rim and core of sample GM yielded significantly younger ages and therefore must record cooling following this last regional metamorphism. The core yields a garnet-hypersthene age of $1018 \pm 7 \mathrm{Ma}$ (Fig. $1 \mathrm{e})$ and, if the plagioclase analysis is included, $1011 \pm 11 \mathrm{Ma}(\mathrm{MSWD}=42.4)$. The age for the rim is $1029 \pm 3 \mathrm{Ma}$ (Fig. 1f). The slightly younger $\mathrm{Sm}-\mathrm{Nd}$ age for the core compared to the rim indicates that re-equilibration in the core continued at lower temperatures than in the rim. This surprising observation can be explained by differences in the grain size of garnet. Due to the large amount of hypersthene, plagioclase and biotite inclusions, the size of individual pieces of garnet in the core is ca. $0.5 \mathrm{~cm}$. In contrast, the rim consists of ca. $5 \mathrm{~cm}$ wide solid garnet with only minor inclusions. The correlation of grain size in samples GM and CCL with the Sm-Nd ages suggests that equilibration of the Sm-Nd system is probably caused by volume diffusion.

The interpretation of the garnet $\mathrm{Sm}-\mathrm{Nd}$ ages from sample GM as cooling ages is consistent with the observation that sphene from the nearby Snowy Mountain dome yielded a $\mathrm{U}-\mathrm{Pb}$ age of $1033 \mathrm{Ma}$ [34]. This age is most likely a cooling age because peak metamorphism reached at least $700^{\circ} \mathrm{C}$ in this area [29], well above the $T_{c}$ of $600-650^{\circ} \mathrm{C}$ characteristc for sphene [34].

\section{Discussion}

The $T_{\mathrm{c}}$ proposed in this study for the Sm-Nd system in garnet is in the range suggested by Humphries and Cliff [25] but significantly lower than that proposed by Cohen et al. [14] and Jagoutz [15]. In order to evaluate whether the $T_{c}$ derived in this study is consistent with other data, $\mathrm{Sm}-\mathrm{Nd}$ ages of garnets from other studies have to be considered. For this evaluation only the $\mathrm{Sm}-\mathrm{Nd}$ ages of garnets for which other reliable age constraints and temperature information on the same samples, or samples from the same general area, are available can be used.

Ashwal and Wooden [41] obtained two isochrons for a garnet-bearing mafic gabbro dike and a sample from the layered ultramafic sequence in the Mt. Marcy anorthosite massif in the central Adirondacks, which is located to the north of Gore Mountain. The ages of $995 \pm 19$ $\mathrm{Ma}$ and $973 \pm 19 \mathrm{Ma}$ are based on mineral isochrons that include a whole rock analysis. Basu et al. [40] used garnet, wollastonite and diopside (their sample GWD1) from the Lewis Mine (Central Adirondacks) to obtain a Sm-Nd isochron with an age of $1010 \pm 10 \mathrm{Ma}$. The ages obtained are similar or younger than the $\mathrm{U}-\mathrm{Pb}$ sphene ages of 1033-991 Ma from this part of the Adirondacks [34]. This relationship supports a $T_{\mathrm{c}}$ for the Sm-Nd system in garnet that is similar to or slightly lower than $T_{\mathrm{c}}$ for the $\mathrm{U}-\mathrm{Pb}$ system in sphene. In contrast, a Sm-Nd garnet-plagioclase-whole rock isochron determined by Basu and Pettingill [42] for an anorthositic sample from the Snowy Mountain dome in the central Adirondacks yielded an age of $1095 \pm 7 \mathrm{Ma}$. This age indicates that the Sm-Nd system in this sample survived a later granulite facies metamorphism that reached temperatures of up to $700^{\circ} \mathrm{C}$ [29]. This is the only sample found that seems to show evidence of a $T_{c}$ in excess of $700^{\circ} \mathrm{C}$ for garnets with a grain size of $<0.5 \mathrm{~cm}$.

In granulites from southern Calabria (Italy) Schenk [43] obtained a Sm-Nd garnet age that is $75 \mathrm{Myr}$ younger than the $\mathrm{U}-\mathrm{Pb}$ monazite ages but $35 \mathrm{Myr}$ older than the $\mathrm{K}$-Ar hornblende ages. The $T_{c}$ for the $\mathrm{U}-\mathrm{Pb}$ system in monazite is ca. $725^{\circ} \mathrm{C}$ [45] and $T_{\mathrm{c}}$ for the $\mathrm{K}-\mathrm{Ar}$ system in slowly cooled hornblende is about $480^{\circ} \mathrm{C}$ [20]. Assuming a constant cooling rate, the $T_{\mathrm{c}}$ for the $\mathrm{Sm}-\mathrm{Nd}$ system in this garnet is $560^{\circ} \mathrm{C}$. A significant number of Sm-Nd mineral ages have been obtained from crustal eclogites [e.g., 11,44]. However, since no age information on metamorphic minerals with a $T_{\mathrm{c}}$ above $600^{\circ} \mathrm{C}$ is available for 
almost all of these eclogites, these studies cannot be used to constrain $T_{c}$ for the $\mathrm{Sm}-\mathrm{Nd}$ system in garnets.

The data presented here, together with the data from studies where temperature and other relevant age information are available, are consistent with a $T_{\mathrm{c}}$ for garnet of approximately $600^{\circ} \mathrm{C}$. This value is significantly lower than the $T_{\mathrm{c}}$ proposed by Cohen et al. [14] and Jagoutz [15]. In both of these studies $[14,15]$ no independent age constraints were available for comparison. It was also assumed that the temperature obtained through geothermometers could be correlated with the time given by the $\mathrm{Sm}-\mathrm{Nd}$ isochron. Since different cations exhibit different diffusion behavior in the same mineral [e.g., 46] the geothermometers are expected to record temperatures that do not necessarily correspond to the time given by the chronometer. In addition, in the studies by Cohen et al. [14] and Jagoutz [15] the metamorphic temperatures were estimated using a garnet-clinopyroxene thermometer and the temperatures obtained with this thermometer may not be reliable [2]. This problem is particularly serious since the clinopyroxenes contain an appreciable amount of $\mathrm{Al}$, which makes it difficult to calculate the activities for the various end-member components unambiguously.

Thin pigeonite lamellae found in some clinopyroxenes from the Norwegian coronites [47], have been used to suggest that the mineral assemblages found in these rocks formed at temperatures in excess of $900^{\circ} \mathrm{C}$. The presence of these pigeonite lamellae, however, cannot be used in support of high metamorphic temperatures as such lamellae are most probably metastable features that developed significantly below the stability temperatures of coarse pigeonite [e.g., 48].

The preservation of major and trace element zoning in garnets up to apparently $900^{\circ} \mathrm{C}$ was used by Cohen et al. [14] as an argument that Sm and $\mathrm{Nd}$ should also have preserved their prograde distribution. As shown in this study (Table 3) the $\mathrm{Sm} / \mathrm{Nd}$ ratios in different aliquots of garnet from the same sample show significant variability that is well outside analytical error. In addition, the garnets from Gore Mountain preserve prograde zoning in the major element compositions (Table 2). Despite this well-preserved zoning, the garnets record cooling ages, and therefore reached isotopic equilibrium, some time after they grew. This observation supports evidence that isotope heterogeneities can be erased much more easily than concentration gradients [e.g., 49]. For this reason, chemical diffusion data can only be used as an approximation and upper limit for the calculation of $T_{\mathrm{c}}$ for the corresponding isotope systems. Studies in regional metamorphic terranes show that major element zoning in garnet (ca. $0.1-1 \mathrm{~cm}$ ) is only preserved up to upper amphibolite conditions [50] and there is no evidence that garnets from terranes which experienced temperatures in excess of $700^{\circ} \mathrm{C}$ preserve significant, prograde, major element zoning. This finding is consistent with recent experimental studies which indicate complete rehomogenization of major elements in garnets at ca. $700^{\circ} \mathrm{C}$ during a regional metamorphic episode [51]. It is expected that, at about $900^{\circ} \mathrm{C}$, even garnets several centimeters in length will have lost their prograde, major element zoning. Therefore, we argue that the temperature estimates for the formation of the Norwegian coronites are too high, as is consequently, the proposed $T_{\mathrm{c}}$ for the Sm$\mathrm{Nd}$ system in these garnets.

Within the compositional range investigated in this study (Table 2; Fig. 3 ), the $T_{\mathrm{c}}$ for all metamorphic garnets $0.1-0.5 \mathrm{~cm}$ in length is ca. $600^{\circ} \mathrm{C}$. Comparison of the major element chemistry of the garnets with the corresponding cooling curves indicates a slight increase in the $T_{\mathrm{c}}$ with increasing $\mathrm{Mg} / \mathrm{Fe}$. However, since the uncertainties in the $T_{\mathrm{c}}$ of the various minerals used to construct the cooling curves are at least $30^{\circ} \mathrm{C}$, the uncertainties in these curves are large. Therefore, the possible correlation of the derived $T_{\mathrm{c}}$ with composition is not considered to be significant. A $T_{\mathrm{c}}$ of ca. $600^{\circ} \mathrm{C}$ allows one to obtain prograde information on garnets using the Sm-Nd system up to mid-amphibolite facies conditions. In high grade metamorphic terranes $\mathrm{Sm}-\mathrm{Nd}$ garnet ages obtained on typical grain sizes can yield information only on the cooling history. If it is desired to obtain prograde information on higher grade garnets using the Sm-Nd system it would be necessary to obtain garnets that are several centimeters in diameter.

The $T_{\mathrm{c}}$ for the $\mathrm{Sm}-\mathrm{Nd}$ system in garnets proposed in this study is consistent with the commonly observed phenomenon that garnets from 
upper mantle xenoliths yield ages close to the time of the eruption rather than the age of formation of the garnet [e.g., 10,52-54]. There may be an exception to this if the rock consists only of garnet and clinopyroxene. Since clinopyroxenes have a $T_{\mathrm{c}}$ (at least for $\mathrm{Sm}$ ) that may be as high as $800^{\circ} \mathrm{C}$ for slowly cooled rocks [55], the garnets in such bi-mineralic rocks cannot exchange after the pyroxene has closed to diffusion. In these rocks it might be possible to obtain a reliable age for the temperature of equilibration [15]. However, to test this hypothesis it would be necessary to find garnet-clinopyroxene rocks from areas where other temperature and age information is available. Since the concentrations of rare earth elements in pyroxenes are much higher than in garnet, it may be sufficient if only the rims of the pyroxene eqilibrate with the garnet and lead to a much lower $T_{c}$. Another case where garnets may provide information on high-temperature processes are diamondiferous mantle xenoliths. As shown by Richardson et al. [56], garnets that grew in the mantle can preserve their Sm-Nd systematics if they are included in diamond. However, in this case, diffusion is limited by the diamond and is independent of the behavior of $\mathrm{Sm}-\mathrm{Nd}$ in garnet.

The results in this study imply that the $\mathrm{Sm}-\mathrm{Nd}$ systematics in metamorphic garnet record cooling rather than mineral growth in most cases. Only very large and inclusion-free garnets may record prograde information in upper amphibolite facies or higher grade rocks. Nevertheless, this technique can provide important information on the early cooling history of mafic, high grade metamorphic rocks for which it is difficult to obtain age information with any other chronometer. In addition, the technique can be used to obtain prograde information for lower amphibolite facies rocks.

\section{Acknowledgements}

Aspects of this study were funded by National Science Foundation grants EAR 82-12764, 8616061, 88-05083, 89-03805, 89-15986, 90-04302 and 90-04413. G. Davies, C. DeWolf, S. Mukasa, M. Ohr and Z. Sharp read earlier versions of this paper and made many helpful suggestions. We would like to thank R. Keller for technical assis- tance; and S. Chakraborty and J. Ganguly for providing a preprint of their paper on element diffusion in garnet. Reviews by $\mathbf{R}$. Cliff and two anonymous reviewers led to the clarification of important points in this paper.

\section{References}

1 R. Powell and T.J.B. Holland, An internally consistent data set with uncertainties and correlations: 3 , Applications to geobarometry, worked examples and computer program. J. Metamorph. Geol. 6, 173-204, 1988.

2 E.J. Essene, Thermobarometry of metamorphic rocks, in: Evolution of Metamorphic Belts, J.S. Daly, R.A. Cliff and B.W.D. Yardley, eds., Geol. Soc. London Spec. Publ. 43, 1-44, 1989.

3 F.S. Spear and J. Selverstone, Quantitative P-T paths from zoned minerals. Theory and tectonic application, Contrib. Mineral. Petrol. 83, 348-357, 1983.

4 J. Selverstone, F.S. Spear, G. Franz and G. Morteani, High pressure metamorphism in the SW Tauern Window, Austria: P-T paths from hornblende-kyanite-staurolite schists, J. Petrol. 25, 501-531, 1984.

5 F.S. Spear, J. Selverstone, D. Hickmott, P. Crowley and K.V. Hodges, $P-T$ paths from garnet zoning: a new technique for deciphering tectonic processes in crystalline terranes, Geology 12, 87-90, 1984.

6 F.S. Spear and D. Rumble, Pressure, temperature, and structural evolution of the Orfordville Belt, west-central New Hampshire, J. Petrol. 27, 1071-1093, 1986.

7 S.R. Bohlen, Pressure-temperature-time paths and a tectonic model for the evolution of granulites, J. Geol. 95, 617-632, 1987.

8 M.R. St.-Onge, Zoned poikiloblastic garnets: P-T paths and syn-metamorphic uplift through $30 \mathrm{~km}$ of structural depth, Wopmay Orogen, Canada, J. Petrol. 95, 196-208, 1987.

9 F.S. Spear, Relative thermobarometry and metamorphic P-T paths, in: Evolution of Metamorphic Belts, J.S. Daly, R.A. Cliff and B.W.D. Yardley, eds., Geol. Soc. London Spec. Publ. 43, 63-81, 1989.

10 O. van Breemen and C.J. Hawkesworth, Sm-Nd isotopic study of garnets and their metamorphic host rocks, Trans. R. Soc. Edinburgh Earth Sci. 71, 97-102, 1980.

11 M.B. Mørk and E.W. Mearns, Sm-Nd isotopic systematics of a gabbro-eclogite transition, Lithos 19, 255-267, 1986.

12 E.W. Mearns, Sm-Nd ages of Norwegian garnet peridotite, Lithos 19, 269-278, 1986.

13 P.J. Patchett and J. Ruiz, Nd isotopic ages of crust formation and metamorphism in the Precambrian of eastern and southern Mexico, Contrib. Mineral. Petrol. 96, 523-528, 1987.

14 A.S. Cohen, R.K. O'Nions, R. Siegenthaler and W.L. Griffin, Chronology of the pressure-temperature history recorded by a granulite terrane, Contrib. Mineral. Petrol. 98, 303-311, 1988.

15 E. Jagoutz, Nd and Sr systematics in an eclogite xenolith from Tanzania: evidence for frozen mineral equilibria in 
the continental lithosphere, Geochim. Cosmochim. Acta 52, 1285-1293, 1988.

16 K. Mezger, G.N. Hanson and S.R. Bohlen, U-Pb systematics of garnet: Dating the growth of garnet in the late Archean Pikwitonei Granulite Domain at Cauchon and Natawahunan Lakes, Manitoba, Canada, Contrib. Mineral. Petrol. 101, 136-148, 1989.

17 K. Mezger, G.N. Hanson and S.R. Bohlen, U-Pb ages of metamorphic rutiles: application to the cooling history of high grade terranes, Earth Planet. Sci. Lett. 96, 106-118, 1990.

18 J.N. Christensen, J.F. Rosenfeld and D.J. DePaolo, Rates of tectonomorphic processes from rubidium and strontium isotopes in garnet, Science 244, 1465-1469, 1989.

19 M.H. Dodson, Closure temperature in cooling geochronological and petrological systems, Contrib. Mineral. Petrol. 40, 259-274, 1973.

20 T.M. Harrison, Diffusion of ${ }^{40} \mathrm{Ar}$ in hornblende, Contrib. Mineral. Petrol. 78, 324-331, 1981.

21 T.M. Harrison, I. Duncan and I. McDougall, Diffusion of ${ }^{40} \mathrm{Ar}$ in biotite: temperature, pressure and compositional effects, Geochim. Cosmochim. Acta 49, 2461-2468, 1985.

22 E.B. Watson, T.M. Harrison and F.M. Ryerson, Diffusion of $\mathrm{Sm}, \mathrm{Sr}$ and $\mathrm{Pb}$ in fluorapatite, Geochim. Cosmochim. Acta 49, 1813-1823, 1985.

23 J.W. Purdy and E. Jäger, K-Ar ages on rockforming minerals from the Central Alps, Mem. Ist. Geol. Mineral. Univ. Padova 30, 1-321, 1976.

24 G.A. Wagner, G.M. Reimer and E. Jäger, Cooling ages derived by apatite fission track, mica $\mathrm{Rb}-\mathrm{Sr}$ and $\mathrm{K}-\mathrm{Ar}$ dating: the uplift and cooling history of the Central Alps, Mem. Ist. Geol. Mineral. Univ. Padova 30, 1-28, 1977.

25 F.J. Humphries and R.A. Cliff, Sm-Nd dating and cooling history of Scourian granulites, Sutherland, NW Scotland, Nature 295, 515-517, 1982.

26 W.J. Harrison and B.J. Wood, An experimental investigation of the partitioning of REE between garnet and liquid with reference to the role of defect equilibria, Contrib. Mineral. Petrol. 72, 145-155, 1980.

27 R.A. Cliff, Isotopic dating in metamorphic belts. J. Geol. Soc. London 142, 97-110, 1984.

28 K. Mezger, S.R. Bohlen and G.N. Hanson, Metamorphic history of the Archean Pikwitonei Granulite Domain and the Cross Lake subprovince, Superior Province, Manitoba, Canada, J. Petrol. 31, 483-517, 1990.

29 S.R. Bohlen, J.W. Valley and E.J. Essene, Metamorphism in the Adirondacks. I: Petrology, pressure, and temperature, J. Petrol. 26, 971-992, 1985.

30 M.A. Cosca, J.F. Sutter and E.J. Essene, Cooling, uplift and erosion history of the Ontario Grenville Province: constraints from ${ }^{40} \mathrm{Ar} /{ }^{39} \mathrm{Ar}$ thermochronometry, Tectonics 10, 959-977, 1991.

31 T.E. Krogh, L. Heaman, N. Machado, D. Davis and W. Weber, U-Pb geochronology program, Northern Superior Province, Manitoba Dep. Energy Mines Rep. Field Act. 1986, 178-180, 1986.

32 T.C. Onstott and M.W. Peacock, Argon retentivity of hornblendes: a field experiment in a slowly cooled metamorphic terrane, Geochim. Cosmochim. Acta 51, 28912903, 1987.
33 J. McLelland, J. Chiarenzelli, P. Whitney and Y. Isachsen, $\mathrm{U}-\mathrm{Pb}$ zircon geochronology of the Adirondack Mountains and implications for their geologic evolution, Geology 16, 920-924, 1988.

34 K. Mezger, C.M. Rawnsley, S.R. Bohlen and G.N. Hanson, $\mathrm{U}-\mathrm{Pb}$ garnet, sphene, monazite and rutile ages: implications for the duration of high-grade metamorphism and cooling histories, Adirondack Mts., New York, J. Geol. 99, 415-428, 1991.

35 R.M. Easton, Geochronology of the Grenville Province; part I: compilation of data; part II: synthesis and interpretation, in: The Grenville Province, J.M. Moore, A. Davidson and A.J. Baer, eds., Geol. Assoc. Can. Pap. 31, 127$174,1986$.

36 A. Davidson and O. van Breemen, Baddeleyite-zircon relationships in coronitic metagabbro, Grenville Province, Ontario: implications for geochronology, Contrib. Mineral. Petrol. 100, 291-299, 1988.

$37 \mathrm{O}$. van Breemen and $\mathrm{A}$. Davidson, $\mathrm{U}-\mathrm{Pb}$ zircon and baddeleyite ages from the Central Gneiss Belt, Ontario, in: Radiogenic Age and Isotopic Studies, Report 3, Geol. Surv. Can. Pap. 89-2, 85-92, 1990.

38 K. Mezger, B.A. van der Pluijm, E.J. Essene and A.N. Halliday, Ancient crustal tectonics: U-Pb geochronology of the Grenville orogen in Ontario, Canada, Contrib. Mineral. Petrol., submitted, 1992.

39 L.M. Anovitz and E.J. Essene, Pressure-temperature constraints on the metamorphism of the Grenville Province, Ontario, J. Petrol. 31, 197-241, 1990.

40 A.R. Basu, B.E. Faggart and M. Sharma, Implications of Nd-isotopic study of Proterozoic garnet amphibolites and wollastonite skarns from Adirondack Mountains, New York, 28th Int. Geol. Congr., Abstr. 1, pp. 95-96, 1989.

41 L.D. Ashwal and J.L. Wooden, $\mathrm{Sr}$ and $\mathrm{Nd}$ isotope geochronology, geologic history, and origin of the Adirondack Anorthosite, Geochim. Cosmochim. Acta. 47, 1875$1885,1983$.

42 A.R. Basu and H.S. Pettingill, Origin and age of Adirondack anorthosites re-evaluated with $\mathrm{Nd}$ isotopes, Geology 11, 514-518, 1983.

43 V. Schenk, The exposed crustal cross section of southern Calabria, Italy: Structure and evolution of a segment of Hercynian crust, in: Exposed Cross-Sections of Continental Crust, M.H. Salisbury and D.M. Fountain, eds., NATO ASI Ser. 317, pp. 21-42, Kluwer, Dordrecht, 1990.

44 H.-G. Stosch and G.W. Lugmair, Geochemistry and the evolution of MORB-type eclogites from the Münchberg Massif, southern Germany, Earth Planet. Sci. Lett. 99, 230-249, 1990.

45 R.R. Parrish, U-Pb dating of monazite and its application to geologic problems, Can. J. Earth Sci. 27, 1431-1450, 1990.

46 R. Freer, Diffusion in silicate minerals and glasses: a data digest and guide to the literature, Contrib. Mineral. Petrol. $76,440-450,1981$.

47 M. Mellini, R. Oberti and G. Rossi, Crystal chemistry and microstructure of pyroxenes and amphiboles in the coronas of the Bergen Arcs and Sogneford region, W. Norway, Period. Mineral. 52, 45-51. 
48 H.W. Jaffe, P. Robinson, R.J. Tracy and M. Ross, Orientation of pigeonite exsolution lamellae in metamorphic augite: correlation with composition and calculated optimal phase boundaries, Am. Mineral. 60, 9-28, 1975.

49 D.R. Baker, Tracer versus trace element diffusion: Diffusional decoupling of $\mathrm{Sr}$ concentration from isotopic composition, Geochim. Cosmochim. Acta. 53, 3015-3023, 1989.

50 B.W.D. Yardley, An empirical study of diffusion in garnet, Am. Mineral. 62, 793-800, 1977.

51 S. Chakraborty and J. Ganguly, Compositional zoning and cation diffusion in garnets, in: Diffusion, Atomic Ordering and Mass Transfer, J. Ganguly, ed., Chap. 4, Springer, Berlin, 1991.

52 E. Jagoutz, R.W. Carlson and G.W. Lugmair, Equilibrated
$\mathrm{Nd}$-unequilibrated $\mathrm{Sr}$ isotopes in mantle xenoliths, Nature 286, 708-710, 1980.

53 R.S. Cohen, R.K. O'Nions and D.B. Dawson, Isotope geochemistry of xenoliths from East Africa: Implications for development of mantle reservoirs and their interaction, Earth Planet. Sci. Lett. 68, 209-220, 1984.

54 A. Zindler and E. Jagoutz, Mantle cryptology, Geochim. Cosmochim. Acta 52, 319-333, 1988.

55 M. Sneeringer, S.R. Hart and N. Shimizu, Strontium and samarium diffusion in diopside, Geochim. Cosmochim. Acta 48, 1589-1608, 1984.

56 S.H. Richardson, J.J. Gurney, A.J. Erlank and J.W. Harris, Origin of diamonds in old enriched mantle, Nature 310, 198-202, 1984. 